\title{
Studies on Biology and Management of Apple Scab Incited by Venturia inaequalis
}

\author{
Annu $^{1}$, Rinku Rani ${ }^{2}$ and J.R. Sharma ${ }^{2}$ \\ ${ }^{1}$ Department of Plant Pathology, ${ }^{2}$ Department of Horticulture, CCS HAU, Hisar, \\ Haryana, India \\ *Corresponding author
}

\begin{tabular}{|l|}
\hline Ke y w o r d s \\
Biology and \\
Management, \\
Apple scab, \\
Venturia inaequalis \\
\hline Article Info \\
\hline $\begin{array}{l}\text { Accepted: } \\
\text { 04 December } 2018 \\
\text { Available Online: } \\
\text { 10 January } 2019\end{array}$ \\
\hline
\end{tabular}

A B S T R A C T

Apple (Malus $\times$ domestica) is an important fruit crop cultivated worldwide. Apple orchards are exposed to a diverse set of environmental and biological factors that affect the productivity and sustainability of the apple cultivation. Many of the efforts for apple production rely on reducing the incidence of fungal diseases, and one of the main diseases is apple scab caused by the fungus Venturia inaequalis (Cooke) Wint. Apple scab is the most devastating important disease of cultivated apple causing economic losses in terms of fruit quality and yield in many apple growing areas. Apple scab attacks foliage, blossoms and fruits, resulting in the defoliation of trees and making the fruits unmarketable. If the disease is not controlled effectively, more than 80 percent fruits of susceptible cultivars can be damaged. Depending on the severity of disease, 10 to 15 or even more fungicidal applications are usually needed for efficient control. The uncontrolled disease may result in almost devastation of whole crop. The main strategy used for scab control is still the frequent application of fungicides throughout the season. However, selection pressure has lead to the evolution of fungicide-resistant strains of scab that represent a threat to the apple industry. Therefore, all the research work in apple growing regions will be focus on identifying and creating commercial varieties with long lasting resistance characteristics and develop alternative strategies to manage apple scab. Main strategies for effectively managing apple scab includes use of resistant cultivars, tolerant rootstock, effective control of primary and secondary infection through use of an integrated crop management system, biological control, use of biotechnological approaches that maximizes yield and quality of apple.

\section{Introduction}

Apple (Malus $x$ domestica Borkhausen) is an important fruit species widely cultivated in the temperate regions of the world (Harris et al., 20002). It ranks third in terms of production with annual production of about
84.6 million tons (FAOSTAT, 2014). Apple is a major industrial fruit and millions of people are associated with it. However like any other crop species many diseases cause huge economic losses to the growers. Usually, apples are consumed fresh or after storage for up to 6 months or even longer. It can be also 
an important raw material for many fields of processing industry like juice, sauce, slices, vinegar and cider (Vejl et al., 2003; Folta and Gardiner, 2009). Apple is attacked by several pathogens for example fungi, bacteria, viruses, mycoplasmas and nematodes. Among fungal diseases is the main problem for commercial apple production in temperate and humid regions. It has been reported that apple is host to over 70 infectious diseases; most of these diseases are caused by pathogenic fungi. They cause root rots, leaf blights, leaf spots, blossom blights, fruit decay, fruit spots, canker and post-harvest decay. Among the common fungal diseases, apple scab is the major fungal disease in commercial apple production in temperate and humid regions of the world (Sandskar, 2003). Apple scab is caused by Venturia inaequalis (Cooke) Wint. The first report on scab was published by Fries in Sweden in 1819 (Fries, 1819), but the oldest clue to the existence of scab dates from 1600, in a painting by Michelangelo Caravaggio ('The Supper at Emmaus'), held at the National Gallery, London (MacHardy et al., 2001). Venturia inaequalis has a wide geographical range and is found in almost all region in which apples are grown commercially. However, the disease is more severe in temperate region with cool, moist climates during early spring (MacHardy, 1996). Direct infection of fruits and pedicels results in yield losses. In addition, severe leaf damage can lead to a weakened tree with reduced flower bud formation (Verma and Sharma, 1999). If the apple scab is chemically controlled losses can be minimized, but the production costs increase together with increasing health and ecological concerns (Patrascu et al., 2006). A well-integrated approach is usually needed to achieve successful disease management, for example improve the environment and selection of a suitable site for the orchard, selection of resistant or tolerant rootstocks and grafts (scion) varieties, application of fungicides and biological disease control are among the tools used to control apple scab disease (Jonsson, 2007; Dewasish and Amal, 2010). Since the late nineteenth century, apple scab has been extensively investigated, and substantial information covering all key aspects of the biology and genetics of the fungus and the epidemiology and control of the disease has been published and reviewed by Machardy (1996) and Bowen et al., (2011). In contrast to the efforts devoted to investigating Venturia inaequalis, little work has been conducted on Venturia spp. affecting other fruit trees. This difference in research effort and number of publications, however, does not directly reflect the importance of the host crop worldwide. The difference might be explained by (i) minor investments in these non-apple crops, (ii) less specialized management directed at the non-apple crops, and (iii) the common use of the information developed for Venturia inaequalis for managing the other fruit scabs. Concerning the last point, researchers generally assume that infection of any scab fungus may occur under environmental conditions similar to those required by Venturia inaequalis. The Mills and Laplante's (1954) table, which is the most popular system for scheduling fungicides against apple scab, has been broadly recommended for management of pear scab (Sobreiro and Mexia, 2000; Mitcham and Elkins, 2007; Travis et al., 2012; Elkins et al., 2016), cherry scab (Schweizer, 1958), peach scab (Keitt, 1917; Pineau et al., 1991), and loquat scab (Ramos, 2008). However, there is no clear evidence that the environmental conditions conducive for infection are similar for all of these Venturia species. In fact, recent studies have revealed important differences concerning the environmental requirements for infection by $F$. eriobotryae and $F$. oleagineum vs. Venturia inaequalis (Viruega et al., 2011; Gonzalez-Dominguez et al., 2013). In addition, substantial differences exist in the 
ecophysiologies and the life cycles of their hosts. Objectives of this review are: to summarize the review and simplify the use of different disease control measures in an integrated management program, and different defense mechanisms of apple to Venturia inaequalis.

\section{Taxonomy}

Apple scab is caused by a pathogen fungus including two different states: Venturia inaequalis, the perfect (sexual) or saprophytic state and Spilocaeapomi Fr., the imperfect (asexual) or parasitic state (Jamar, 2011). Venturia inaequalisis belongs to genus Venturia (Lepoivre, 2003). It can be classified it to the subdivision of Ascomycota, class Loculoascomyctes, order Pleosporales and family Venturiaceae (MacHardy, 1996). Spilocaeapomi Fr. is placed in the subdivision of Deuteromycota, class Hyphomycètes, order Moniliales (Lepoivre, 2003). Basically, Venturia inaequalis only infects Malus species. It is a non-pathogen to all non Malus plants. However, pathogens responsible for scab on Malus sp. And Pyracantha sp. are considered as two formae speciales belonging to Venturia inaequalis (Cam et al., 2002). Yet, while the genus Malus is the main host of Venturia inaequalis, not all Malus genotypes are susceptible.

Venturia inaequalis was one of the first studied ascomycetes and remains to be a practical implementation for numerous genetic studies, for example, its sexual compatibility and the heritability of pathogenicity. This is caused by similarity to other parasites that infect young living tissues without obvious damage for a long period as well as its ability to be cultivated and mate in vitro (Vaillancourt and Hartman, 2000). Among the characteristics that make Venturia inaequalis so acceptable to genetic studies include its genotype and phenotype stability for many years and large diversity in nature.
Living tissues are infected by heterothallic fungus Venturia inaequalis (Jha et al., 2009).

\section{Apple scab physiological races}

The concept of race as a fixed genetic unit is not valid for an obligatory sexually reproducing organism. The terminology 'race' used for Venturia inaequalis indicate an isolate capable of infecting and sporulating on a particular host resistant to other isolates; as such it should be called physiological race as in the early literature. In other words, in the case of an obligatorily sexually reproducing pathogen like Venturia inaequalis, the word 'race' indicates nothing more than the presence or lack of virulence traits with respect to specific hosts on which the isolate is tested. Eight physiological races of scab are currently defined according to their virulence on 'specific host' varieties as shown in table 1. The first three of these were identified by Shay and Williams (1956) Race 1 is taken as a well sporulating isolate on popular domestic cultivars and eliciting flecks or necrotic lesions without sporulation on Malus clones Dolgo, R12740- 7A and Geneva (Shay and Williams, 1956). Race 2 can sporulate on 'Dolgo,' 'Geneva' and certain offspring of 'R12740-7A.' Race 3 is characterized as being able to sporulate on 'Geneva,' otherwise being the same as race 1 , and race 4 differs from 1 by sporulating on those offspring of ' $\mathrm{R} 12740-7 \mathrm{~A}$ ' that race 2 is not able to sporulate on. Race 5 has the ability to sporulate on carriers of the $\mathrm{Vm}$ resistance and can thus circumvent the resistance of Malus micromalus. Race 6 first appeared at Ahrensburg, in Germany, in the nineteeneighties (Bus et al., 2005). It is virulent on most of the varieties containing the Vf gene, but not on clone.

\section{Symptoms of the disease and host range}

The most visible and severe symptoms of apple scab occur on leaves and fruits. It also 
visible on sepals and petals, young shoots and bud scales (Sandskar, 2003; Daniels, 2013; Turechek, 2004; Giraud et al., 2011). The earliest symptoms of the apple scab are usually appearing on the underside of emerging cluster leaves. However, symptoms may first develop on the upper side of these leaves in cases where significant infection was delayed. Young lesions are velvety brown to olive green and have feathery, indistinct margins. Lesions expand with time and may coalesce with other leaf lesions. The number of lesions can vary from very few to several hundred per leaf. Young leaves with significant infection often curl, shrivel and fall from the tree. However, it is not atypical for infected leaves to remain on the tree for the entire season. The term "sheet scab" refers to the condition when the entire leaf surface is covered with the disease; when this occurs, leaves typically shrivel and fall to the ground. Eventually, fungal growth stops and the lesions develop distinct margins. The infected leaf tissue around lesions often becomes thickened and lead to bulging of the infected area and a corresponding cupping of the area underneath the leaf lesion.

Lesions on the petiole (leaf stem) extend along the length of the petiole and are similar in appearance to those on the leaf. Severe infection of the petiole typically leads to a yellowing of the infected leaf and eventual leaf drop. On the fruit, young lesions appear similar to those on leaves. Although the entire surface of the fruit is susceptible to infection, lesions often cluster around the calyx end of the fruit (Fig. 1). As lesions get older they become brown and corky and take on a "scabby" appearance. Early infections kill the expanding tissue which often results in deformed fruit. As lesions age, they typically crack and provide sites that may serve as an opening to invasion by secondary pathogens. Infections late in the season are usually not detectable until after harvest when the fruit are in storage. This is referred to as "pin-point scab". The term "storage scab" refers to incipient infections that were too small to see prior to fruit storage or may be the result of infections during storage that occur as a result of sporulation from older scab lesions.

\section{Life cycle and epidemiology of apple scab}

The ascomycete Venturia inaequalis infects members of the subfamily Maloideae, and causes the disease apple scab. Venturia inaequalis is a hemibiotrophic fungus. It overwinters mostly in dead fallen leaves, in which microscopic flask-formed black fruiting bodies, called pseudothecia, are formed. In the early spring, the ascospores inside pseudothecia start to mature and in suitable weather conditions, when leaves become wet after the rain, spores are forcibly ejected into the air (Sandskar, 2003; Jamar, 2011). The life cycle of Venturia inaequalis can be subdivided into two phases: primary or sexual phase and secondary or asexual phase (Figure 1). The primary phase mainly occurs in winter and the secondary in summer (MacHardy, 1996; Verma and Sharma, 1999). Primary phase/Sexual reproduction phase generally creates primary infection. The fungus over winters remains as pseudothecia (sexual fruiting bodies) that develop in apple leaf litter following a short phase (maximum of four weeks) of saprophytic vegetative growth after leaf abscission. As most ascomycetes, Venturia inaequalis is anisogamous: the sex organs are differentiated into ascogonia in the female and antheridia in the male haploid parent. Also, it is heterothallic: plasmogamy of the two gametangia can only proceed if the antheridium and the ascogonium originate from parents of opposite mating type, i.e. carry different mating type alleles on the mating type (MAT) locus. The mating type is the result of a complex interaction between the gene products encoded by the different 
genes which are situated on MAT locus (Gisi et al., 2002; Billiard et al., 2011). The ascospores are produced in the asci which are in turn carried by the pseudothecium (Daniels, 2013). The optimal temperature for the development of ascogonia and maturation of the ascospores is $8-12^{\circ} \mathrm{C}$ and $16-18^{\circ} \mathrm{C}$, respectively (Turechek, 2004). The primary inoculum is released by rainfall in spring whithin five to nine weeks and mainly consists of ascospores (Sandskar, 2003). The sexual spores have inner and outer cell wall. The outer cell wall is fragile and thin. The inner cell wall is elastic and thick that protects the ascospores from winter conditions (Jha et al., 2009). The asci also have a double cell wall. The release of ascospores takes place if the inner and outer cell walls of the asci break. During rainfall, a thin water film is developed around the pseudothecia due to asci adsorb water and expand. Because of the building pressure first the outer cell wall breaks and, after some time, also the inner. The release of ascospores is mainly takes place during the day favoured by sunlight (Biggs and Stensvand 2014; Rossi et al., 2001). The spores are spread up to $200 \mathrm{~m}$ from the source by the wind (Turechek, 2004). The primary inoculum lands on the host plant surface (inoculation) after which an infection can take place when conditions are favourable. Free moisture on the leaf surface is necessary for spore germination. Once initiated, the germination will continue as long as the relative humidity $(\mathrm{RH})$ is more than 95\% (Turechek, 2004). Spore germination does not guarantee infection. The further development of the fungus is dependent on the temperature, the duration of leaf wetness and the susceptibility of the plant itself and of the inoculated plant organ such as leaves vs. sepals and petals, age of the leaf. Meteorological criteria defining the duration of (leaf) wetness required for infection at different temperatures were first proposed by (Daniels, 2013), and are known as Mills' periods. These criteria have become a standard tool, in combination with electronic weather monitoring, for identifying when conditions favourable for infection occur, so that fungicide applications can be targeted effectively. Infection risk is greatest early in the growing season when leaves and fruit are young and at their most susceptible developmental phase ( $\mathrm{Xu}$ and Robinson, 2005). The germ tubes arising from ascospores penetrate through the cuticle not through stomata via an appressorium and differentiate to form sub cuticular runner hyphae. At regular intervals, from these sub cuticular hyphae, multilayered, pseudo parenchymatous structures, termed stromata, formed. Stromata are made up of laterally dividing cells and these are presumed to obtain nutrients from the sub cuticular space (Lepoivre, 2003; Jha et al., 2009). Secondary phase/Asexual reproduction of Venturia inaequalis starts by producing conidia, these conidia responsible for secondary infection. Spilocae apomi is known as the conidial stage of the Venturia inaequalis. The conidia are olive/brown colored single-cells with width of $6-12 \mu \mathrm{m}$ and length of $12-22 \mu \mathrm{m}$. They are produced one after the other at the tip of hyphae termed as conidiophores. The conidia and conidiophores give a distinctive velvety exterior to the newly formed lesions of scab as mass produced on the thick mat of mycelium (Vaillancourt and Hartman, 2000). Once distributed by wind and flopping rain, conidia land on an apple blossom or fruit and leaves, and stick to the surface and germinate. The hyphae germination breaks through the cuticle and develops a new infection (Fig. 2).

The conidia of Venturia inaequalis are able to adhere and germinate also on non-host plants. Like in the case of ascospores, the discharging of conidia depends on temperature as well as moisture and humidity, and may develop from few days to a couple of weeks after initial leaf infection. The 
favourable conditions for the development of secondary infection by conidia are wet and cool days in spring, summer and fall (Biggs and Stensvand, 2014). Many cycles of conidial production and secondary infection take place during particular growing period under the suitable weather conditions. Late infection in autumn may not be detected. But, during storage, it can affect fruits (Sandskar, 2003).

\section{Control measures of the disease}

\section{Host plant resistance}

Besides considerations such as fruit quality, productivity, ease of tree management and commercial criteria, it is also essential use varieties that are more resistant to apple scab diseases and other pest. Therefore, now a day there is more than 100 apple cultivars are released with reaction to Venturia. inaequalis (Table 2) (Beckerman, 2006). To reduce fungicide applications, apple breeders are currently introgressing disease resistance from wild Malus accessions into commercial lines. The first attempts were made 100 years ago. Genetic resistance to the apple scab pathogen was originally found in a crab apple, Malus floribunda 821 and therefore most of today's scab-resistant cultivars rely on a single introduction of scab resistance from Malus floribunda 821, referred to as Vf (Gessler and Pertot, 2012). Currently cultivars with scab resistance incorporate several dominant resistance genes, most of which are located at the Vf locus of the apple genome. Generally, in apple scab disease management, resistance breeding is the most efficient and effective method. But, this has been complicated by the presence of several races or forms of the fungus, and the fact that plants resistant to one race may be susceptible to another, because of the scab strains' ability to adapt to a specific host plant (Carisse et al., 2006). So, the immunity of some species of wild Malus or certain cultivated genotypes can break down if new scab races/forms appear (Benaouf and Parisi, 2000). 'Golden Delicious' is good example which was regarded as relatively scab resistant at the beginning of 20 century and has now become extremely susceptible (Carisse et al., 2006). Therefore, disease management practices on scab resistant cultivars, should take into consideration the development of new strains of Venturia inaequalis that may be virulent on the cultivars resistant to only one strain of the pathogen (Parisi et al., 1993). Commonly, apple cultivars differ greatly in regard to their resistance and susceptible level to scab. For instance, in Europe and New Zealand, over 50 scab-resistant cultivars have been released based on apple breeding programs. Redfree, Prima and Liberty are good examples of resistant cultivars (Table 2) (Lepoivre, 2003; Benaouf and Parisi, 2000; Shane, 2016) (Fig. 3).

\section{Resistant varieties}

There are a number of apple varieties that have high levels of resistance to apple scab disease (Carisse and Dewdney, 2002). Currently, there are six major genes that impart resistance to apple scab: Vf (Malus floribunda), $\mathrm{Vr}$ (Russian apple seedling), Vbj (Malus baccata Jackii), Vb (Hansen's baccata), Va (Antonovka), and Vm (Malus micromalus susceptible to race 5). Each of these genes, except for $\mathrm{Vm}$, confer resistance to all known races of the pathogen. Nearly all resistant commercial varieties contain the $\mathrm{Vf}$ gene. Resistant varieties include 'Prima', 'Priscilla', 'Macfree', 'Florina', 'Liberty', 'Jonafree', and 'Pioneer' to name a few. These varieties are planted primarily in organic orchards and not widely planted in many commercial orchards. The role of cultivar susceptibility has received little attention in disease management, particularly in forecasting. The original Mills curves were 
developed for the highly susceptible cultivar 'McIntosh'. Aldwinckle (Aldwinckle, 1974) ranked 51 varieties but made no attempt to adjust Mills' curves based on his findings. Olivier (1984) also ranked cultivars into susceptibility groups for the selection of an appropriate infection curve but does not seem to have verified his results to confirm his classification. Schwabe (1980) in South Africa tested commercial varieties for differences in leaf wetness required for infection and reported that all cultivars required between 3-6 hrs of wetness for ascospore infection but made no mention of the relative susceptibility of the cultivars. In a 3 year study, Ellis et al., (1998) evaluated the efficacy and economics of using an inorganic (primarily sulfur) and conventional spray program to manage apple scab on the scabresistant variety 'Liberty' and the scabsusceptible variety 'McIntosh' in Ohio. During the three year period, an average of 5 and 9 applications of fungicide were applied under the conventional program and 7 and 12.6 applications under the inorganic program on 'Liberty' and 'McIntosh', respectively. The reduction in the number of sprays on 'Liberty' was associated with the elimination of all pre-petal fall applications which are usually targeted for apple scab. This resulted in a cost savings of $73 \%$ and $57 \%$ for the inorganic and conventional, respectively, for apple scab disease management on 'Liberty' compared to 'McIntosh'. Despite the savings, apple scab resistant varieties are not widely grown as there is virtually no consumer demand for these varieties.

\section{Structural and biochemical defence mechanisms of Apple for Venturia inaequalis}

Both structural (cuticle) and biochemical (relative oxygen species, enzymes, defence proteins, phytoalexins, phytoanticipins, hormones, etc.) defence mechanisms have role against apple scab disease causing pathogen. Cuticle is one of the outer structural defence mechanisms of plants. It is a protective film cover the epidermis of leaves, young shoots and other aerial plant organs without periderm (Kolattukudy, 1996). It consists of lipid and a three dimensional hydrocarbon polymer impregnated with cuticular wax Beisson et al., 2012). The physical and chemical properties of cuticular waxes have role in vital functions for plants i.e. limits water loss, inhibits the growth and development of disease causing pathogens such as bacteria and fungi (Dominguez et al., 2011). The pathogen Venturia inaequalis needs certain amount of free water on surface of leave in order to survive and the composition, the thickness and robustness of cuticle also determine the speed with which the Venturia inaequalisis able to penetrate the host plant. Generally, the properties of the cuticle and the hydrophilicity of the leaf change during development. This would play a role in ontogenic resistance (Jha et al., 2009). The role of a number of PR proteins has been demonstrated in apple scab defence. A comparative study by (Gau et al., 2004) between the apoplastic protein accumulation of the Rvi6 resistant cultivar 'Remo' and the susceptible cultivar 'Elstar' found that, the apoplast is formed by the continuum of cell walls of adjacent cells as well as the extracellular matrix. It is important for all the plant's interaction with its environment. By means of two-dimensional gel electrophoresis (2-DE) and mass spectrometry, differences in concentration of a number of $\mathrm{PR}$ proteins between both cultivars (resistant and susceptible)were detected. In the susceptible cultivar 'Elstar' the number of detectable apoplastic proteins more than doubled after infection. Most of the extra proteins detected had an isoelectric point between 4 and 5 (Gau et al., 2004). The concentrations of the respective PR-2, PR-3 and PR- 8 proteins $\beta$ 1,3-glucanase $(36-40 \mathrm{kDa})$, chitinase $(27-28$ 
$\mathrm{kDa})$ and endochitinase type III (27-28 kDa) are higher prior to infection in cv. 'Remo' than in 'Elstar'. After infection by Venturia inaequalis, the concentrations in 'Elstar' become similar to those in 'Remo'. This suggests a constitutive accumulation of these proteins only in the resistant cultivar. B-1, 3glucanase, chitinase and endochitinase are capable to hydrolyze the fungal cell wall. The chito-oligosaccharides that are formed as a result of the endochitinase activity would induce defense mechanisms through a yet uncharacterized pathway (Paris et al., 2009). A thaumatin-like protein (PR-5) is constitutively present in higher concentrations in the apoplast of the resistant cv. Remo. In the susceptible 'Elstar', the accumulation increases upon infection. Thaumatin $(21 \mathrm{kDa})$ is a sweet-tasting protein and considered a prototype for a PR protein (Gau et al., 2004). These authors also detected osmotin like proteins and a PR-1 protein (15-16 $\mathrm{kDa})$. A possible explanation is that this protein would play a role in the recognition of the pathogen and the onset of the defence response. It would interact with pathogen's effectors and induce a non-specific, systemic resistance (Blein et al., 2002). The lipid transfer protein also transfers phospholipids through membranes and would play a role in the formation of the cuticle and epicuticular wax (Diaz-Perales et al., 2002). The reduced accumulation of the Mald3 gene that codes for this lipid transfer protein was confirmed by Paris et al., (Paris et al., 2009). The accumulation of a number of Mald1 proteins of the ribonuclease type (PR-10) is increased after infection in HcrVf2 transformed 'Gala' (Paris et al., 2009). Besides, the expression of genes that code for defencing-like proteins (PR-12) is also increased after infection. Plant defences would exert their antifungal activity by altering fungal membrane permeability and by inhibiting fungal macromolecule biosynthesis (Thevissen et al., 1999). Phenolic compounds of apple and their relationship to scab resistance Phenolic compounds would play important role in the defence of apple against Venturia inaequalis. For instance, the elimination of phenyl alanine ammonia-lyase (PAL), a very important enzyme in the phenol synthesis signal transduction pathway, turns the resistant cv. 'Sir Prize' susceptible (Mayr et $a l ., 1997)$. PAL catalyzes the first step in the phenyl propanoid pathway and is therefore involved in the biosynthesis of phenolic compounds such as phenyl propanoids, flavonoids and lignin in plants. The activity of PAL is known to be induced dramatically in response to various stimuli, including pathogenic attack (MacDonald and D'Cunha, 2007). The main phenolic compounds are present in both susceptible and resistant cultivars. However, the absolute amounts and relative proportions of these compounds differ. Rvi6 cultivars generally have higher total phenol contents, as well as greater amounts of particular phenolic molecules, as compared with susceptible cultivars, even as these levels vary over the course of the season (Petkovsek et al., 2009) and are influenced by cultural practices (Petkovsek et al., 2010). An example of a phenolic compound that is present in higher amounts in older leaves and in resistant apple cultivars is chlorogenic acid (Petkovsek et al., 2009). Not only the phenols themselves, but also their degradation products also contribute to resistance development. Phlorizin for example is the most prominent phenolic glycoside in apple and has an inhibitory action on Venturia inaequalis (Gosch et al., 2009). It is mainly present in the cuticle and thus would influence the most critical moment in the survival of the fungus after inoculation: the germination and penetration in the subcuticular space. Venturia inaequalis converts phlorizin to phloretin. This compound has an antifungal action as well (MacHardy, 1996). Gessler et al., (2006) concluded from the studies that it is not the 
constitutive presence of phenols that causes resistance, but rather a local accumulation and transformation activated by an elicitor. Infection of apple by Venturia inaequalis also leads to an accumulation of flavanols in the region adjacent to the scab lesions (Mayr and Treutter, 1998). Malusfuran and derivatives of dibenzofuran are produced upon fungal attack and suppress the germination and growth of Venturia inaequalis (Jha et al., 2009).

\section{Cultural control methods}

Standard cultural and sanitary practices are used to reduce scab infection such as leaf shredding, burning or burying leaves in the soil, and application of $5 \%$ urea (approximately 40 pounds urea in 100 gallons of water) onto leaves on the floor, which help to reduce the development of Venturia inaequalis (Giraud et al., 2011; Ziems, 2009). However, these inoculum reduction practices may be expensive and impractical for some commercial operations, and never fully eradicate all sources of primary inoculum (Sutton et al., 2000; Merwin et al., 1994). In general, to prevent spread of inoculum from crab apple trees to apple trees, crab apple trees at the edges of the apple orchard should be removed. Regular pruning is also necessary for the proper sunlight penetration and air circulation in the canopy and between trees for the prevention of scab development. Selecting sites that provide more than six hours of sunlight per day, spacing trees adequately, and following proper pruning practices to open the tree canopy can be also minimize or even prevented the disease (Beckerman, 2006a).

\section{Pruning}

To reduce apple scab, it is necessary to keep the leaves as dry as possible, in other words, to avoid planting too close together, to ventilate the canopy by pruning and to avoid planting in wet, low-lying areas (Corroyer and Petit, 2002). Kolbe (1983) found that orchards which promote circulation of air through the rows and between the rows by means of appropriate pruning have lower levels of scab in the long term. Holb (2005) compared three pruning models (intense, moderate and none) on two very susceptible cultivars (cv. Jonagold and cv. Mutsu), two susceptible cultivars (cv. Elstar and cv. Idared) and two resistant cultivars (cv. Liberty and cv. Prima) in an organic apple orchard. He concluded, notably, that intense pruning of susceptible cultivars results in significantly less scab on the leaves and fruit as compared to other two models. Simon et al., (2006) showed the favourable effects of centrifugal as training compared to conventional solaxetraining on scab control, interpreting these results as being due to better ventilation within the tree and, therefore, a microclimate which is unfavourable to scab.

\section{Inoculum reduction}

Scab over winters mainly on dead leaves fallen on the ground and these are therefore the main source of the primary inoculum that causes contamination the following spring (MacHardy et al., 2001). The two main ways of discouraging the primary inoculum are (i) to reduce the mass of scabbed leaf litter and (ii) to prevent Venturia inaequalis developing in the litter that remains (MacHardy et al., 2001). Several other studies have also shown the effects of sanitary practices such as burning or burying leaves in the soil (Gomez et al., 2004), leaf shredding (Vincent et al., 2004; Holb et al., 2006) and a combination of shredding and using urea (Sutton et al., 2000) on reducing scab inoculum. These studies found that an ascosporic inoculum reduction of between 40 and $95 \%$ and a correlated scab reduction of 45 to $85 \%$.Collecting leaves from the ground in the inter-rows in autumn along with burying the leaves left along the row has 
a positive effect in discouraging primary contamination (Gomez et al., 2004). Gomez et al., (2004) reported that for two consecutive years the practice of 'raking and ridging' reduced the severity of scab on the fruit by 68 to $74 \%$, depending on the year. Burchill et al., (1965) first showed that application of 5\% urea to English orchards in the autumn completely suppressed ascospore production the following spring. Burchill (1968) treated Bramley's Seedling trees at two sites in Kent with a post-harvest, pre- leaf fall application of 5\% urea; scab lesions on blossom- spur leaves were reduced by $59 \%$ and $46 \%$, respectively, the following spring compared to the untreated control. Mitre et al., (2012) studied the effect of applications of urea 5\% after harvest but before leaf-fall, as foliar application, in order to restrict perithecial production by Venturia inaequalis in a commercial super intensive apple orchard situated near Cluj-Napoca, Romania. The results found that large reductions in spore production, often as high as 70 to $80 \%$, following application of 5\% urea. Spraying the surface of the leaves on the ground with urea $5 \%$ reduced primary infection by about $60 \%$

\section{Fertilization}

Professional fruit grower requires regular supplement of minerals to warrant fruit set and quality. Heavy nitrogen fertilization supports tree and fruit growth ie. it is a prominent controlling tool for yield. An enhanced vegetative growth of apple trees, however, is often correlated with an increasing susceptibility to pathogens such as Venturia inaequalis (Leser and Treutter, 2005). This may be result of the concomitant decrease of phenolic compounds by high nitrogen uptake (Leser and Treutter, 2005), indicating that environmental conditions favouring plant growth reduce investment of carbon for defence. Kumar and Gupta (1986) reported that a high level of potassium fertilizers increased resistance of apple tree to scab but a similar effect was not obtained with high levels of phosphorus fertilization.

\section{Biological control methods}

Biological control is the method of controlling or suppressing of plant disease by using other microorganisms (Pal and Gardener, 2006) Several studies have identified different antagonistic agent to manage Venturia inaequalis. Such as, Microsphaeropsis ochracea, which occurs naturally on dead leaves and isolated, as a good antagonist of Venturia inaequalis when applied in August and September resulting in a 95 to $99 \%$ reduction in spring ascospore production as compared to untreated treatments (Carisse and Rolland, 2004). This potential biological control method is not solely sufficient for management of apple scab to commercially acceptable level. Therefore, cultural and potential biological practices would have to be used in combination with a fungicide spray program (MacHardy, 1996). MacHardy (1996) identified two antagonistic fungi, Athelia bombacina and Chaetomium globosum which are potentially useful as biological control agents for Venturia inaequalis. Chaetomium globosum applied during the secondary infection season could be beneficial, it decreases the size and number of lesions, the conidial density and the conidial germ tube germination rate and elongation. Vincent et al., (1986) observed a reduction in spring ascospore production of about 81 and $85 \%$ following autumn application of Athelia bombacina and Microsphaeropsis ochracea, respectively. Several studies showed that some fungi such as Auerobasidium botrytis, Cladosporium spp. and several epiphytic yeast strains from the apple tree plyllosphereare capable to inhibit Venturia inaequalis germination and mycelial growth 
on apple tree plantlets by up to $80 \%$. Some strains of Trichoderma longibrachiatum also found antagonistic towards Venturia inaequalis, decreasing ascospore production from naturally infected leaves (Fiss et al., 2003; Palani and Lalithakumari, 1999) The earthworms, Lumbricus terrestris are the main natural biological agents for removing dead fallen leaves from orchard floors in winter and early spring (Holb et al., 2006). In grassed-down orchards the number and weight of leaves buried are directly related to the weight of Lumbricus terrestris in the soil. In some orchards containing between 275 and $367 \mathrm{~kg}$ of Lumbricus terrestris per hectare, the earthworms can bury up to $184 \mathrm{~kg}$ of leaves per hectare, which is equivalent to $90 \%$ of the total autumn leaf fall (MacHardy, 1996). At the same time, this is a major contribution to the turnover and redistribution of organic matter in the soil.

\section{Chemical control method}

On susceptible apple cultivars, apple scab is primarily managed through the application of fungicides (Diaz-Perales et al., 2002). At the end of 19th century first chemical fungicides, especially protective fungicides based on copper against pathogen Venturia inaequalis, were discovered. However, in some countries, the use of copper as fungicides in apple fruit is totally prohibited. These constraints drive growers to use large quantities of sulphurbased fungicides, which may have other drawbacks. Recently based on epidemiological trainings, mineral fungicides like sulfur with less toxicity were developed (Jamar, 2011). Farmers have to treat apple cultivars, which are vulnerable for scab, many times with fungicides per season (Soriano et al., 2009). Also in organic apple production, applications of mineral substances like sulfur, lime sulfur, and copper salts are essential for effective scab management to preserve the resistance of cultivars and to prevent initial infection (Daniels, 2013; Beckerman, 2009). Preventing early or initial infection of apple scab produced by ascospores is the most critical step toward successful control of later leaf and fruit infections, on which chemical control of apple scab is concentrated. Later fungicide sprays are targeted at other fungal diseases as well as against secondary infection of apple scab. The strategies of using fungicides are formed on the base of studies of apple scab epidemiology and biology throughout the years (Alaniz et al., 2014; Cova et al., 2015). In general, growers apply preventive and curative chemical fungicides together for good efficiency that are capable of stopping fungus development (Vaillancourt and Hartman, 2000; Chapman et al., 2011). Even though, regular and welltimed fungicide sprays have proven to be the most commercially practical means of controlling scab for susceptible apple trees, but the first line of defense is to consider scab-resistant apples (Ziems, 2009) and at present, to reduce fungicide applications, enhanced strategies are developed based on a better understanding of the airborne spreading of ascospores, host foliage and fruit area, and the host defenselessness against infection. In addition, repeated application of fungicide for apple scab management result in high costs in terms of money and for the fungicide sprays and in the time dedicated to scab management. Because of increasing pressure on apple growers to reduce pesticide use and reduce production costs, while maintaining a high level of crop quality, we believe it is crucial and timely to simplify and optimize apple scab management (Gessler et al., 2006). Therefore, this is indicating that researchers or growers will focus into new strategies for controlling apple scab in apple production. Generally, selection pressure has resulted in the evolution of fungicide-resistant strains of scab that represent a threat to the industry. For example, dodine was first released in 1959 to control scab, and 10 years later resistance was 
first recorded (MFPMG, 2017; Szkolnik and Gilpatrick, 1969). In addition, resistance of Venturia inaequalis to demethylation inhibitors fungicides was documented in practice (Braun 1994). Strategies to delay the development of resistance to the different classes of fungicides under field conditions rely on restricting the number of applications per season of fungicides in each class and mixing or alternating fungicides of different classes (Lepoivre, 2003). Therefore, the use of compounds or fungicides, acting via elicitation or priming for plant defense enhancement, and the development of new, durable scab-resistant apple cultivars will most likely gain importance in future apple scab management strategies.

\section{Integrated disease management Integrated Disease Management (IDM)}

IDM is a multidisciplinary strategy for disease management that seeks to achieve long-term effectiveness, affordability, and minimal environmental disruption (Fadamiro et al., 2003). IDM tactics include host plant resistance, cultural practices, biological controls and chemical application. All these methods are used in combination and more likely to be effective to managing disease as compared to reliance on a single technique, such as calendar-based pesticide spraying (Trumble, 1998; Shumann. and D'Arcy, 2006). IDM programs for scab control usually focus on reduction of primary inoculum, or reducing fungicidal sprays using predictive models. The pathogen, Venturia inaequalis has high pathogenic variability and new races of the pathogen are evolved frequently.

Therefore, IDM is the most effective approach to minimize the yield losses due to scab. Malavolta and Cross (2009) stated that, IDM has made tremendous progress in terms of tree nutrition, plant protection product spraying quality, restriction on post-harvest treatments, soil management, selection and rate of application of active substances used in disease and pest control and timing of pest treatments, based on an assessment of the actual risk they pose. Pruning in combination with fungicide use has been shown to significantly reduce leaf scab because it improved spray deposition in the tree canopy (Holb, 2005).

Table.1 Physiological races of Venturia inaequalis (Bus et al., 2005; MacHardy, 1996)

\begin{tabular}{|c|c|}
\hline Races & Pathological characteristics on apple cultivars \\
\hline Race 1 & Non sporulating lesion on Dolgo, R 12740-7A (a Russian cultivar) and Geneva \\
\hline Race 2 & Sporulating lesions on Dolgo, Geneva and some progenies of R 12740-7A \\
\hline Race 3 & $\begin{array}{l}\text { Sporulating lesions on Geneva, and non sporulating lesion on Dolgo, R 12740- } \\
7 \mathrm{~A}\end{array}$ \\
\hline Race 4 & $\begin{array}{l}\text { Non sporulating lesion on Dolgo, Geneva and sporulating lesion on those } \\
\text { progenies of R12740-7A on which race } 2 \text { isolates cannot sporulate }\end{array}$ \\
\hline Race 5 & Sporulating lesions on Vm R gene containing cultivars \\
\hline Race 6 & $\begin{array}{l}\text { Sporulating lesions on Vf hybrids but cannot infect Malus floribunda } 821 \\
\text { containing Vfh R gene }\end{array}$ \\
\hline Race 7 & $\begin{array}{l}\text { Can infect cultivars having Vf and Vfh R gene but cannot infect Golden } \\
\text { delicious which contains Vg gene }\end{array}$ \\
\hline Race 8 & Can infect Golden delicious, Royal gala, and cultivars containing Vh8 R gene \\
\hline
\end{tabular}


Table.2 List of apple cultivars reaction to apple scab

\begin{tabular}{|c|c|c|c|c|c|c|c|c|c|}
\hline $\begin{array}{l}\text { Apple } \\
\text { cultivar }\end{array}$ & $\begin{array}{l}\text { Apple } \\
\text { scab }\end{array}$ & $\begin{array}{l}\text { Apple } \\
\text { cultivar }\end{array}$ & $\begin{array}{l}\text { Apple } \\
\text { Scab }\end{array}$ & $\begin{array}{l}\text { Apple } \\
\text { cultivar }\end{array}$ & $\begin{array}{l}\text { Apple } \\
\text { Scab }\end{array}$ & $\begin{array}{l}\text { Apple } \\
\text { cultivar }\end{array}$ & $\begin{array}{l}\text { Apple } \\
\text { Scab }\end{array}$ & $\begin{array}{l}\text { Apple } \\
\text { cultivar }\end{array}$ & $\begin{array}{l}\text { Apple } \\
\text { Scab }\end{array}$ \\
\hline $\begin{array}{l}\text { Adam's } \\
\text { Permain }\end{array}$ & MR & $\begin{array}{l}\text { Crimson } \\
\text { Crisp }\end{array}$ & VR & $\begin{array}{l}\text { Golden } \\
\text { Delicious }\end{array}$ & VS & Jonamac & $S$ & Murray & $\mathrm{R}$ \\
\hline Akane & $\mathrm{R}$ & $\begin{array}{l}\text { Delicious } \\
\text { (Red) }\end{array}$ & S & Gold Rush & VR & Jonathan & $\mathrm{S}$ & $\begin{array}{l}\text { Mutsu } \\
\text { (Crispin) }\end{array}$ & VS \\
\hline Ambrosia & VS & Dayton & VR & $\begin{array}{l}\text { Granny } \\
\text { Smith }\end{array}$ & $\mathrm{S}$ & Julyred & VS & $\begin{array}{l}\text { Newtown } \\
\text { Pippon }\end{array}$ & S \\
\hline $\begin{array}{l}\text { Ashmead's } \\
\text { Kerne }\end{array}$ & MR & $\begin{array}{l}\text { Early } \\
\text { McIntosh }\end{array}$ & $S$ & Gravenstein & $\mathrm{S}$ & Lodi & $\mathrm{S}$ & NJ90 & MR \\
\hline Baldwin & $S$ & Empire & VS & $\begin{array}{l}\text { Grimes } \\
\text { Golden }\end{array}$ & $\mathrm{R}$ & Macfree & $\mathrm{R}$ & $\begin{array}{l}\text { Northern } \\
\text { Spy }\end{array}$ & $S$ \\
\hline Beacon & $\mathrm{S}$ & $\begin{array}{l}\text { Enterpris } \\
\mathrm{e}\end{array}$ & VR & Haralson & MR & Macoun & VS & $\begin{array}{l}\text { Nova } \\
\text { Easygrow }\end{array}$ & VR \\
\hline Belmac & $\mathrm{R}$ & $\begin{array}{l}\text { Florina } \\
\text { (Querina) }\end{array}$ & $\mathrm{R}$ & $\begin{array}{l}\text { Honey } \\
\text { Crisp }\end{array}$ & MR & McIntosh & VS & Novamac & VR \\
\hline Braeburn & $S$ & Freedom & VR & $\begin{array}{l}\text { Honey } \\
\text { Gold }\end{array}$ & $\mathrm{R}$ & Melrose & VS & Nova Spy & $\mathrm{R}$ \\
\hline Britegold & $\mathrm{R}$ & Fuji & S & Idared & $\mathrm{S}$ & Milton & $\mathrm{S}$ & Paula Red & $\mathrm{R}$ \\
\hline Cameo & $\mathrm{S}$ & Gala & VS & Jerseymac & VS & Moira & $\mathrm{R}$ & Pink Lady & VS \\
\hline Cortland & VS & $\begin{array}{l}\text { Ginger } \\
\text { Gold }\end{array}$ & VS & Jonagold & $\mathrm{S}$ & $\begin{array}{l}\text { Mollies } \\
\text { Delicious }\end{array}$ & $\mathrm{S}$ & $\begin{array}{l}\text { Pinova } \\
\text { (Corrail) }\end{array}$ & $\mathrm{R}$ \\
\hline Prima & VR & $\begin{array}{l}\text { Roxbury } \\
\text { Russet }\end{array}$ & S & $\begin{array}{l}\text { Starkspur } \\
\text { Earliblaze }\end{array}$ & $\mathrm{S}$ & Trent & VR & Winesap & VS \\
\hline Priscilla & VR & Runkel & $\mathrm{R}$ & $\begin{array}{l}\text { Stark } \\
\text { Splendor }\end{array}$ & $\mathrm{S}$ & Viking & $\mathrm{S}$ & $\begin{array}{l}\text { Winter } \\
\text { Banana }\end{array}$ & VS \\
\hline Pristine & VR & $\begin{array}{l}\text { Scarlet } \\
\text { O’Hara }\end{array}$ & VR & Stayman & VS & Wayne & $\mathrm{S}$ & $\begin{array}{l}\text { Wolf } \\
\text { River }\end{array}$ & $\mathrm{R}$ \\
\hline Puritan & $\mathrm{S}$ & Silken & VS & $\begin{array}{l}\text { Summer } \\
\text { red }\end{array}$ & $\mathrm{S}$ & Wealthy & $\mathrm{S}$ & $\begin{array}{l}\text { Yellow } \\
\text { Transpare } \\
\text { nt }\end{array}$ & MR \\
\hline Redfree & $\mathrm{R}$ & Sir Prize & VR & Suncrisp & MS & $\begin{array}{l}\text { Wellingto } \\
\mathrm{n}\end{array}$ & $\mathrm{S}$ & $\begin{array}{l}\text { York } \\
\text { Imperial }\end{array}$ & S \\
\hline $\begin{array}{l}\text { R.I. } \\
\text { Greening }\end{array}$ & $S$ & Spijon & $S$ & Sundance & VR & $\begin{array}{l}\text { William's } \\
\text { Pride }\end{array}$ & VR & Zestar & MS \\
\hline $\begin{array}{l}\text { Rome } \\
\text { Beauty }\end{array}$ & VS & $\begin{array}{l}\text { Stark } \\
\text { Bounty }\end{array}$ & S & & & & & & \\
\hline
\end{tabular}

Abbr: Where, VR=Very Resistant; VS=Very Susceptible; R= Resistant S=Susceptible; MR=Moderately Resistant and MS=Moderately Susceptible) (Jamar, 2011; Jha et al., 2009; Ziems, 2009; Shane, 2016) 
Figure.1 (a) Apple scab lesion in the early stage of development; (b-c) secondary scab lesions on leaves; (d-e) scab lesions on fruits; and (f) pin-point scab (Gessler et al., 2006; Carisse et al., 2006)
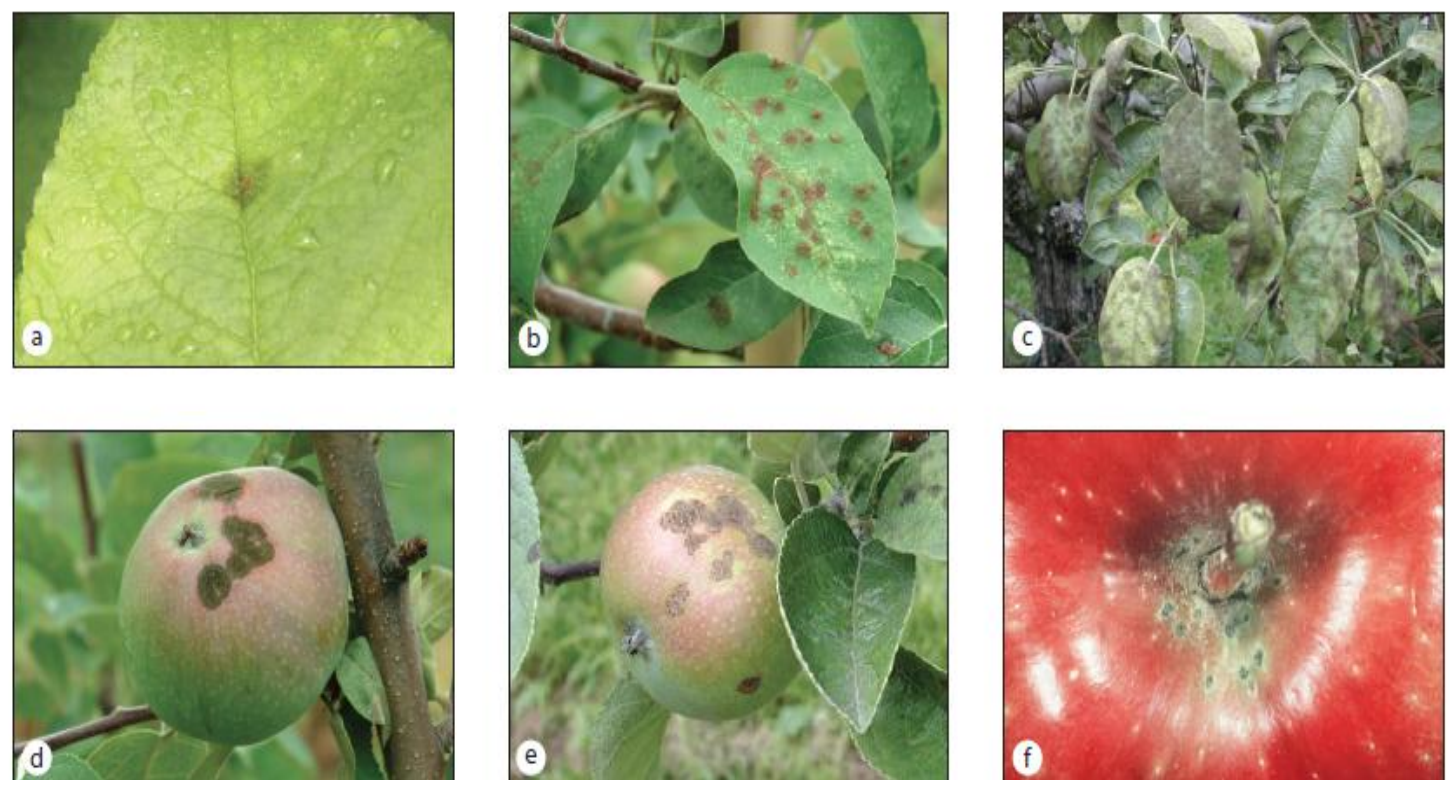

Figure.2 Apple scab disease cycle (Cornell University, NYSAES, Geneva, NY.).

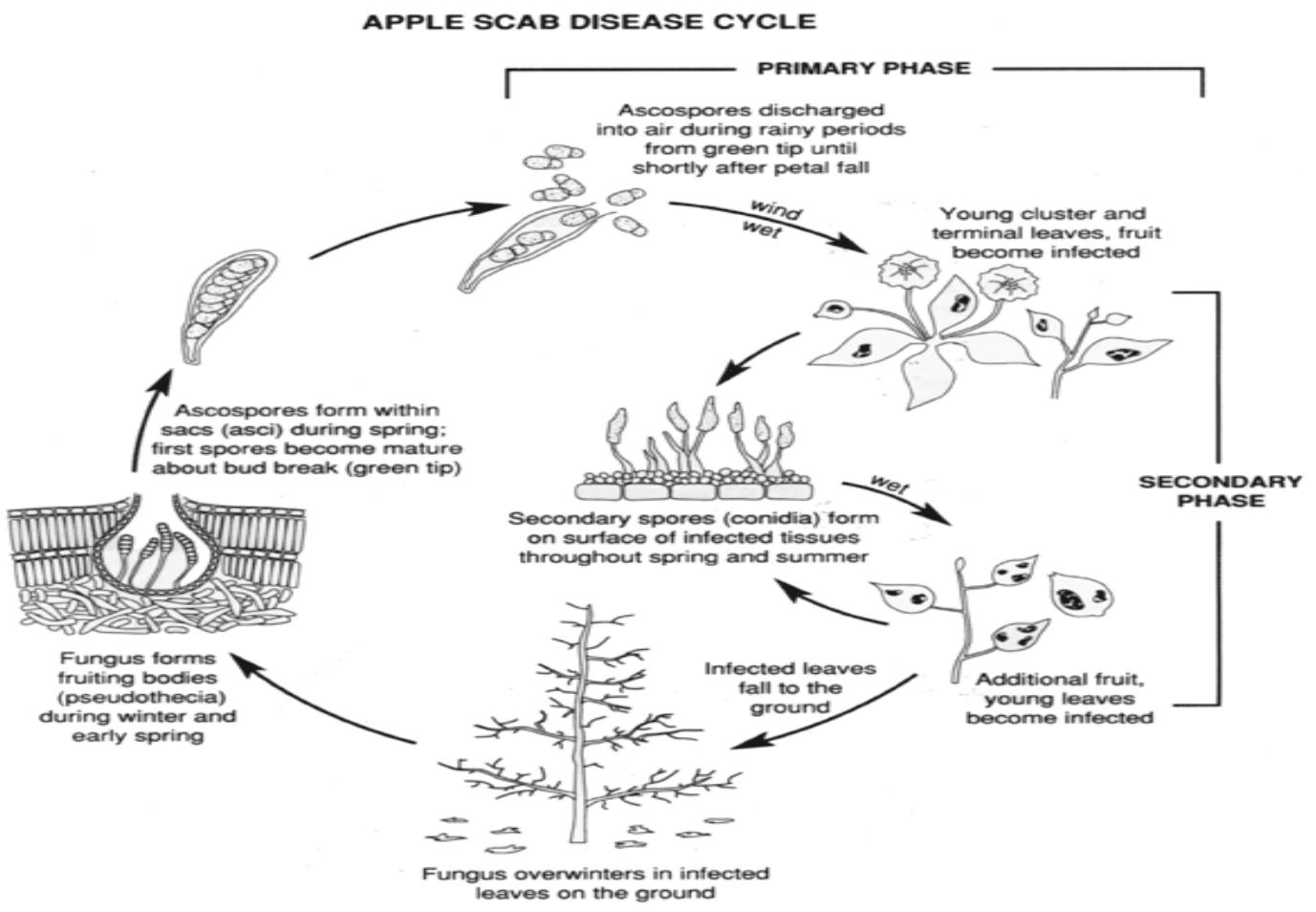


Figure.3 Three reproductive strategies and practices for controlling each reproductive strategy (Jamar, 2011)

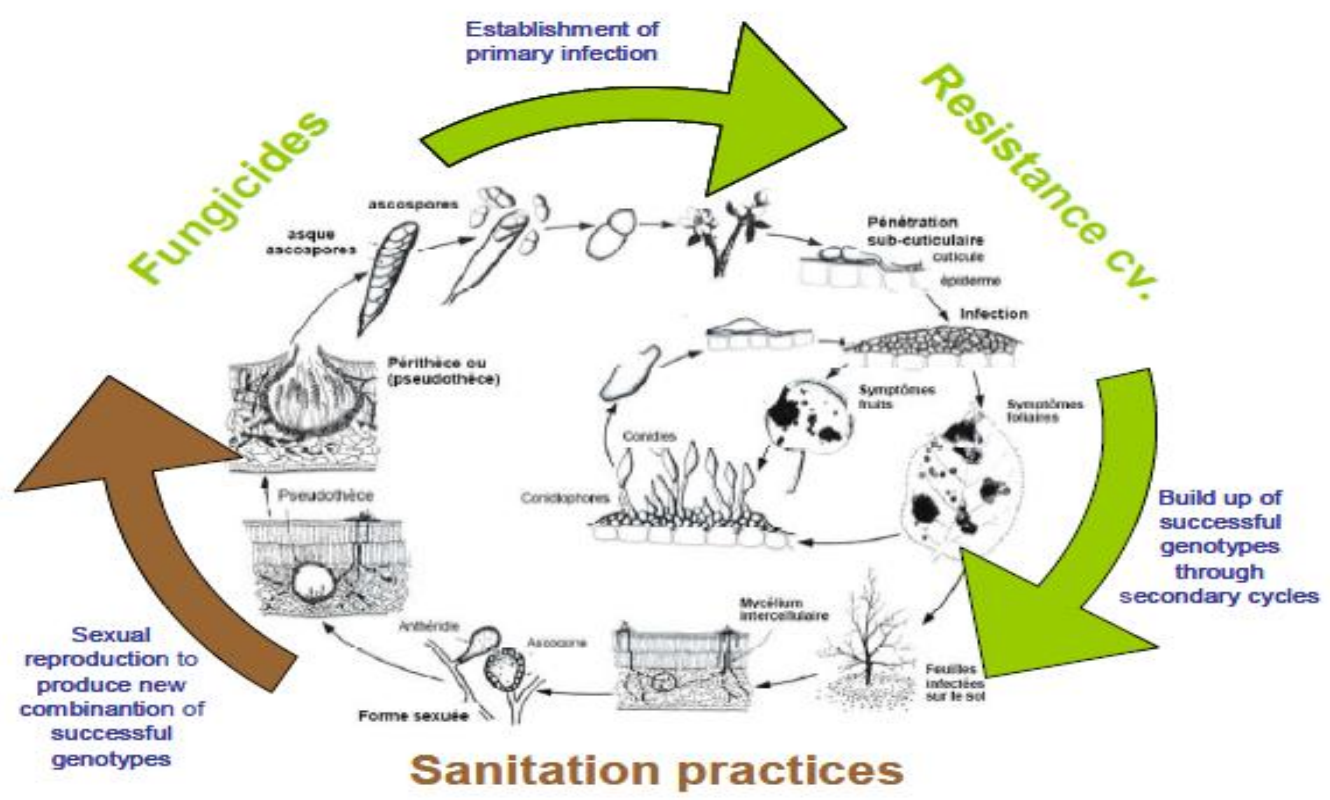

In conclusion, apple scab is economic importance and if not managed, the disease can cause extensive losses following humid and cool weather conditions during the spring months. Direct losses result from fruit infections and indirect losses from defoliation, which can reduce tree vigour, winter hardiness, and subsequent yield. Fungicidal control is generally considered the sole economically feasible control measure against apple scab disease. However, this may change due to the high costs of new fungicides, increased fungicide resistance in populations of Venturia inaequalis, and increasing concerns of environmental pollution and consumers negative perceptions of fungicide use. Therefore, new strategies for development of a durable management of apple scab are clearly necessary. The use of fungicides or compounds, acting via elicitation or priming for plant defense enhancement, and the development of new, durable scab-resistant apple cultivars will most likely gain importance in future apple scab management strategies. Knowledge of the biology and variability of Venturia inaequalis is also a prerequisite for breeding program aimed at obtaining durable resistance to apple scab. Further studies on ecology of Venturia inaequalis and its epidemiology are required to improve current disease management strategies. Both innovative and conventional approaches should be used to investigate the host-pathogen relationship between Malus $\times$ domestica and Venturia inaequalis. Intensive research on the management of apple scab using bio-agents, improved cultural practices and developing resistance varieties should be emphasized in the future to enhance the overall efficacy of both organic and conventional apple production. Generally, integrated disease management (IDM), which combines biological, resistance, cultural and chemical control strategies in a holistic way rather than using a single component strategy proved to be more effective and sustainable for apple scab disease management. Therefore, every country will give a propriety on research in order to: identify and create commercial varieties with lasting resistance characteristics, improve the effectiveness of 
phyto-sanitary practices aimed at reducing the inoculum and develop knowledge of the potential of such practices in order to reduce demand for fungicides, find alternative fungicides to sulfur and copper, refine strategies and protection schemes, optimize treatment timing, improve plant protection product application techniques and develop specific cultural practices that are less favourable to the development of the disease.

\section{References}

Alaniz S., Leoni C., Bentancur O. and Mondino P. (2014) Elimination of summer fungicide sprays for apple scab (Venturia inaequalis) management in Uruguay. Sci Hortic., 165: 331-335.

Aldwinckle H.S. (1974) Field susceptibility of 51 apple cultivars to apple scab and apple powdery mildew. Plant Disease Reporter, 58: 625-629.

Beckerman J. (2006) Disease Susceptibility of Common Apple Cultivars, Fruit Diseases. Perdue Extension, Perdue University, USA.

Beckerman J. (2006a) Apple Scab on Tree Fruit in the Home Orchard: Fruit Diseases. Perdue Extension, Perdue University, USA

Beckerman J. (2009) Managing ScabResistant Apples, Disease Management Strategies for Horticultural Crops. Perdue Extension, Perdue University, USA.

Beisson K.F., Li-Beisson Y. and Pollard M. (2012) Solving the puzzles of cutin and suberin polymer biosynthesis. Curr Opin Plant Biol., 15: 329-337.

Benaouf G. and Parisi L. (2000) Genetics of the host-pathogen relationship between Venturia inaequalis races 6 and 7 and Malus species. Phytopathology, 90: 236-242.

Biggs A.R. and Stensvand A. (2014) Apple scab: Compendium of Apple and Pear Diseases and Pests. American Phytopathological Society Press, T.B. St. Paul, MN, USA.

Billiard S., Lopez-Villaviciencio M., Devier B., Hood M.E. and Fairhead C. (2011) Having sex, yes, but with whom? Inferences from fungi on the evolution of anisogamy and mating types. Biol Rev Camb Philos Soc., 86: 421-442.

Blein J., Coutos-Thevenot P., Marion D. and Ponchet M. (2002) From elicitins to lipid-transfer proteins: a new insight in cell signaling involved in plant defence mechanisms. Trends Plant Sci., 7: 293-296.

Bowen J., Mesarich C., Bus V., Beresford R. and Plummer K. (2011) Venturia inaequalis: the causal agent of apple scab. Mol Plant Pathol., 12: 105-122.

Braun P.G. (1994) Development and decline of a population of Venturia inaequalis resistant to sterol-inhibiting fungicides. Norweg J Agric Sci., 17: 173- 184.

Burchill R.T. (1968) Field and laboratory studies of the effect of urea on ascospore production of Venturia inaequalis (Cke.) Wint. Ann Appl Biol., 62: 297-307.

Burchill R.T., Hutton K.E., Crosse J.E. and Garrett C.M. (1965) The inhibition of the perfect stage of Venturia inaequalis (Cooke) Wint. by urea. Nature, 205: 520

Bus V. G. M., Laurens F. N. D. and van de Weg W. E. (2005) The Vh8 locus of a new gene-for- gene interaction between Venturia inaequalis and the wild apple Malus sieversii is closely linked to the Vh2locus in Malus pumila R12740-7A. New Phytol., 166: 1035-1049.

Cam B.L., Parisi L. and Arene L (2002) Evidence of two formae speciales in Venturia inaequalis, responsible for 
apple and pyracantha. Phytopathology, 92: 314-320.

Carisse O, Jobin T, McFadden-Smith W, Meloche C, Lasnier J (2006) Apple Scab: Improving Understanding for Better Management. Agriculture and Agri- Food Canada, Canada.

Carisse O. and Dewdney M. (2002) A review of non-fungicidal approaches for the control of apple scab. Phytoprotection, 83: 1-29.

Carisse O. and Rolland D. (2004) Effect of timing of application of the biological control agent Microsphaeropsis ochracea on the production and ejection pattern of ascospores by Venturia inaequalis. Phytopathology. 94: 1305-1314.

Chapman K.S., Sundin G.W. and Beckerman J.L. (2011) Identification of resistance to multiple fungicides in field populations of Venturia inaequalis. Plant Dis., 95: 921-926.

Corroyer N. and Petit J.L. (2002) Le pommier. pp. 230-261. In Produire des fruits enAgriculture Biologique. ITAB. 253 p.

Cova V., Bandara N., Liang W., Tartarini S. and Patocchi A. (2015) Fine mapping of the Rvi5 (Vm) apple scab resistance locus in the 'Murray' apple genotype. Mol Breed., 35: 200.

Daniels B (2013) Response of apple (Malus $\times$ domestica) to Venturia inaequalis, the causal agent of apple scab: a real-time PCR and proteomics study. PhD thesis. Catholic University of Leuven, Belgium, 199p.

Dewasish C. and Amal M. (2010) Fruit crops. (3rd edtn), Oxford book company publisher, Jaipur, India.

Diaz-Perales A., Garcia-Cassado G., SanchezMonge R., Garcia-Selles F. and Barber D. (2002) cDNA cloning and heterologous expression of the major allergens from peach and apple belonging to the lipid-transfer protein family. Clin Exp Allergy, 32: 87-92.

Dominguez E., Heredia-Guerrero J.A. and Heredia A. (2011) The biophysical design of plant cuticles: an overview. New Phytol., 189: 938-949.

Elkins B., Gubler W.D. and Adaskaveg J.E. (2016) UC IPM Pest Management Guidelines: Pear. UC ANR Publication, 3455.

Ellis M.A., Ferree D.C., Funt, R.C. and Madden L.V. (1998) Effect of an apple scab-resistant cultivar on use patterns of inorganic and organic fungicides and economics of disease control. Plant Dis., 82: 428-433.

Fadamiro H., Ciborowski J. and Hock H. (2003) Integrated pest management manual for Minnesota apple orchards. A scouting and management guide for key apple pests. Minnesota Department of Agriculture. St. Paul.

FAOSTAT (2014) FAO statistics division.

Fiss M., Barckhausen O., Gherbawy Y., Kollar A. and Hamamoto M. (2003) Characterization of epiphytic yeasts of apple as potential biocontrol agents against apple scab (Venturia inaequalis). J Plant Dis Prot., 110: 513-523.

Folta K.M. and Gardiner S.E. (2009) Plant genetics and genomics: Genetics and genomics of Rosaceae. (6th edtn), Springer Science Business Media, New York, USA.

Fries E. (1819) Spilocacea pomi, $\mathrm{Fr}$ Nov Fl Suec 5: 79.

Gau A., Koutb M., Piotrowski M. and Kloppstech K. (2004) Accumulation of pathogenesis-related proteins in the apoplast of susceptible cultivar of apple (Malus domestica cv. Elstar) after infection by Venturia inaequalis and constitutive expression of PR genes in the cultivar Remo. Eur $J$ Plant Pathol., 110: 703-711. 
Gessler C. and Pertot I. (2012) Vf scab resistance of Malus. Trees, 26: 95108.

Gessler C., Patocchi A., Sansavini S., Tartarini S. and Gianfranceschi L. (2006) Venturia inaequalis Resistance in Apple. Crit Rev Plant Sci., 25: $473-$ 503.

Giraud D.D., Elkins R.B. and Gubler W.D. (2011) Apple and Pear Scab. Plant Pathology. University of California. Statewide Integrated Pest Management. Program Agriculture and Natural Resources.

Gisi U., Sierotzki H., Cook A. and McCaffery A. (2002) Mechanisms influencing the evolution of resistance to Qo inhibitor fungicides. Pest Manag Sci., 58: 859867.

Gomez C., Brun L., Chauffour D., De Le Valee D. and Dumont E. (2004) Effet de la reduction de l'inoculum d'automne sur le développement des épidémies de tavelureen verger de pommiers biologiques. Dans: Journées techniques fruits et legumes biologiques. Saint- Pierre-des- Corps, les 30 nov. \& 1er déc. 2004: pp 45-52, ITAB.

Gonzalez-Dominguez E., Rossi V., Armengol, J. and Garcia-Jimenez J. (2013) Effect of environmental factors on mycelial growth and conidial germination of Fusicladium eriobotryae and the infection of loquat leaves. Plant Dis., 97: 1331-1338.

Gosch C., Halbwirth H., Kuhn J., Miosic S. and Stich K. (2009) Biosynthesis of phloridzin in apple (Malus domestica Borkh.). Plant Sci., 176: 223-231.

Harris S.A., Robinson J.P. and Juniper B.E. (2002) Genetic clues to the origin of the apple. Trends in Genetics, 18(8): 426-430.

Holb I.J. (2005) Effect of pruning on apple scab in organic apple production.
Plant Dis., 89: 611-618.

Holb I.J., Heijne B. and Jeder M. (2006) Effects of integrated control measures on earthworms, leaf litter and Venturia inaequalis infection in two European apple orchards. Agric. Ecosyst. Environ., 114: 287-295.

Jamar L (2011) Innovative strategies for the control of apple scab (Venturia inaequalis [Cke.] Wint.) in organic apple production. $\mathrm{PhD}$ thesis, University of Liege-Gembloux AgroBio Tech, Belgium.

Jha G., Thakur K. and Thakur P (2009) The Venturia apple pathosystem: pathogenicity mechanisms and plant defense responses. $J$ Biomed Biotechnol., 28: 1-10.

Jonsson A. (2007) Organic apple production in Sweden, cultivation and cultivars. $\mathrm{PhD}$ thesis, Swedish University of Agricultural Sciences, Sweden.

Keitt G. (1917) Peach scab and its control. Bull. Dep. Agric. U.S.A. 395: 1-64.

Kolattukudy P.E. (1996) Biosynthetic pathways of cutin and waxes, and their sensitivity to environmental stresses: Plant Cuticles an integrated functional approach. BIOS Scientific publishers Ltd., Oxford, pp. 83-108.

Kolbe W. (1983) Effects of different pruning systems and chemical retardants compared with no pruning on apple trees on yield fruit quality and disease incidence in the long term trial at Hofchen (1959-1982). Erwersobstbau, 25: 246-255.

Kumar J. and Gupta G.K. (1986) Influence of host response and climatic factors on the development of conidial stage of apple scab fungus (Venturia inaequalis). Indian $J$ Mycol Plant Patho., 116: 123- 135.

Lepoivre P (2003) Phytopathologie. De Boek University. Bruxelles. 427p.

Leser C. and Treutter D. (2005) Effects of 
nitrogen supply on growth, contents of phenolic compounds and pathogen (scab) resistance of apple trees. Physiologia Plantarum, 123: 49-56

MacDonald M.J. and D'Cunha G.B. (2007) A modern view of phenylalanine ammonia lyase. Biochem Cell Biol., 85: 273-282.

MacHardy W. (1996) Apple Scab Biology, Epidemiology and Management. American Phytopathological Society Press, St. Paul, MN.

MacHardy W., Gadoury D. and Gessler C. (2001) Parasitic and Biological Fitness of Venturia inaequalis: Relationship to Disease Management Strategies. Plant Dis, 85: 1036-1051.

Malavolta C. and Cross J.V. (2009) Technical Guideline III: IOBC. WPRS Bulletin. (4th edtn), 47, 21p.

Mayr U. and Treutter D. (1998) Flavanols as defence barriers in apple leaves against the apple scab fungus (Venturia inaequalis). Acta Hortic., 466: 79-82.

Mayr U., Michalek S., Treutter D. and Feucht W. (1997) Phenolic compounds of apple and their relationship to scab resistance. J Phytopathol., 145: 69-75.

Merwin I.A., Brown S.K., Rosenberger D.A., Cooley D.R. and Berkett L.P. (1994) Scab resistant apples for the Nort1heastern United States: new prospects and old problems. Plant Dis., 78:4-10.

MFPMG. Midwest Fruit Pest Management Guide (2017) Perdue Extension, Perdue University, USA.

Mills W.D. and LaPlante A.A. (1954) Apple scab: Disease and insects in the orchard. Cornell Extension Bulletin, 711: 20-28.

Mitcham E. and Elkins R. (2007) Pear Production and Handling Manual. California, CA: University of California Publications.
Mitre V., Mitre L., Adriana F., Petrisor C. and Sestras R. (2012) Reducing primary inoculum of apple scab using foliar application of urea in autumn. Bulletin of the University of Agricultural Sciences \& Veterinary, 69: 415-420.

Olivier J.M. (1984) Evolution de la lutte contre la tavelure du pommier. $L a$ Défense des Végétaux, 225: 22-35.

Pal K.K. and Gardener B.M. (2006) Biological Control of Plant Pathogens. The Plant Health Instructor.

Palani P.V. and Lalithakumari D. (1999) Antagonism of Trichoderma longibrachiatum strains to fungicide sensitive and resistant strains of Venturia inaequalis. J Plant Dis Prot., 106: 581-589.

Paris R., Cova V., Pagliarani G., Tartarini S. and Komjanc M. (2009) Expression profiling in HcrVf2-transformed apple plants in response to Venturia inaequalis. Tree Genet Genomes, 5: 81-91.

Parisi L., Lespinasse Y., Guillaumes J. and Kruger J. (1993) A new race of Venturia inaequalis virulent to apples with resistance due to the Vf gene. Phytopathology, 83: 533-537

Patrascu B., Pamfil D., Sestras R., Botez C. and Gaboreanu I. (2006) Marker assisted selection for response attack of Venturia inaequalis in different apple genotype. Not Bot Horti Agrobot Cluj Napoca, 34: 121-133.

Petkovsek M.M., Slatnar A., Stampar F. and Veberic R (2010) The influence of organic/integrated production on the content of phenolic compounds in apple leaves and fruits in four different varieties over a 2-year period. J Sci Food Agric., 90: 23662378.

Petkovsek M.M., Stampar F. and Veberic R. (2009) Seasonal changes in phenolic compounds in the leaves of scab- 
resistant and susceptible apple cultivars. Can J Plant Sci., 89: 745753.

Pineau R., Raymondaud H. and Schiavon M. (1991) Elaboration d'un modèle de prévision des risques d'infection du mirabellier (Prunus domestica L var insititia) parl' agent delatavelure (Cladosporium carpophilum Thumen). Agron. EDP Sci., 11: 561-570.

Ramos N. (2008) Relatório de Aplicação de Modelos de Previsão de Ocorrencia de Inimigosdas Culturas. Casodo Modelo Paraa Cochonilhade S.JoséResultados preliminares. Algarve (Portugal): Direcção Regional de Agricultura e Pescas do Algarve, Patacão. Julho.

Rossi V., Ponti I., Marinelli M., Giosue S. and Bugiani R. (2001) Environmental factors influencing the dispersal of Venturia inaequalis ascospore in orchards air. J Phytopathol., 149: 1119.

Sandskar B. (2003) Apple Scab (Venturia inaequalis) and Pests in Organic Orchards. PhD Thesis, Swedish University of Agricultural Sciences, Alnarp, 39.

Schwabe W.F.S. (1980) Wetting and temperature requirements for apple leaf infection by Venturia inaequalis in South Africa. Phytophylactica, 12: 69-80.

Schweizer H. (1958) Contributions to the biology of the pathogen of cherry and peach scab (Fusicladium cerasi (Rabh.) Sacc. Venturia cerasi Ad. and Cladosporium carpophilum v. Thum). J. Phytopathol., 33: 55-98.

Shane B (2016) Apple Varieties with Significant Scab Resistance, Michigan State University Extension.

Shay J.R. and Williams E.B. (1956) Identification of three physiologic races of Venturia inaequalis.
Phytopathology, 46: 190-193.

Shumann G.L. and D'Arcy C.J. (2006) Essential Plant Pathology. American Phytopathological Society Press. St. Paul, Minnesota USA.

Simon S., Lauri P. E., Brun L., Defrance,H. and Sauphanor B. (2006) Does manipulation of fruit tree architecture affect the development of pests and pathogens? A case study in an organic apple orchard. J. Hortic. Sci. Biotechnol., 81: 765-773.

Sobreiro J. and Mexia A. (2000) The simulation of pear scab (Venturia pirina) infection periods and epidemics under field conditions. Acta Hortic., 525: 153-160.

Soriano J., Joshi S., van Kaauwen M., Noordijk Y. and Groenwold R. (2009) Identification and mapping of the novel apple scab resistance gene $\mathrm{Vd} 3$. Tree Genet Genomes, 5: 475-482

Sutton D.K., MacHardy W.E. and Lord W.G. (2000) Effects of shredding or treating apple leaf litter with urea on ascospore dose of Venturia inaequalis and disease build up. Plant Dis., 84:13191326.

Szkolnik M. and Gilpatrick J.D. (1969) Apparent resistance of Venturia inaequalis to dodine in New York apple orchards. Plant Dis Reports, 53: 861-864.

Thevissen K., Terras F. and Broekaert W. (1999) Permeabilization of fungal membranes by plant defensins inhibits fungal growth. Appl Environ Microbiol., 65: 5451-5458.

Travis J.W., Rytter J. and Yoder K. (2012) Pear Scab (Venturia pirina). Extension Service, West Virginia University.

Trumble J.T. (1998) IPM: overcoming conflicts in adoption. Integra Pest Manage Rev., 3: 195-207.

Turechek W.W. (2004) Apple diseases and their management: Diseases of fruits 
and vegetables. Diagnosis and management. (1st edtn), Kluwer Academic Publishers, Dordrecht.

Vaillancourt L. and Hartman J. (2000) Apple scab. The Plant Health Instructor

Vejl P., Skupinoval S., Blazek J., Sedlak P. and Bardova M. (2003) PCR markers of apple resistance to scab (Venturia inaequalis CKE.) controlled by $\mathrm{Vf}$ gene in Czech apple breeding. Plant Soil Environ, 49: 427-432.

Verma L.R. and Sharma R.C. (1999) Diseases of horticultural crops: fruits. Indus Publishing Company, New Delhi.

Vincent C., Rancourt B. and Carisse O. (2004) Apple leaf shredding as a nonchemical tool to manage apple scab and spotted tentiform leaf miner. Agric. Ecosyst. Environ., 104: 595-
604

Viruega J. R., Roca L. F., Moral J. and Trapero A. (2011) Factors affecting infection and disease development on olive leaves inoculated with Fusicladium oleagineum. Plant Dis., 95: 1139-1146.

Xu X.M. and Robinson J. (2005) Modelling the effects of wetness duration and fruit maturity on infection of apple fruits of Cox's Orange Pippin and two clones of Gala by Venturia inaequalis. Plant Pathol., 54:347-356.

Ziems A.D. (2009) Apple scab: Plant disease. Lincoln Extension, Institute of Agriculture and Natural Resources, University of Nebraska, USA.

\section{How to cite this article:}

Annu, Rinku Rani and Sharma, J.R. 2019. Studies on Biology and Management of Apple Scab Incited by Venturia inaequalis. Int.J.Curr.Microbiol.App.Sci. 8(01): 162-182. doi: https://doi.org/10.20546/ijcmas.2019.801.019 